\title{
Molecular Genetic Variations among Some Punjab Sheep Breeds Using RAPD Analysis
}

\author{
Hafiz Muhammad Waheed ${ }^{1}$, Safdar Ali ${ }^{2}$, Muhammad Sajjad Khan ${ }^{2}$, \\ Muhammad Said ur Rehman', Ghulam Abbas, \\ ${ }^{1}$ Department of Livestock Production \& Management, Pir Mehr Ali Shah Arid Agriculture University Rawalpindi \\ ${ }^{2}$ Department of Animal Breeding \& Genetics, University of Agriculture Faisalabad \\ ${ }^{3}$ Department of poultry science, University of Agriculture Faisalabad
}

Copyright (C) 2015 Horizon Research Publishing All rights reserved.

\begin{abstract}
The present study was carried out on seven sheep breeds (Thalli, Lohi, Salt Range, Kajli, Sipli, Buchi and Hissradale) by Random Amplified Polymorphic DNA (RAPD) analysis using 21 random decamer primers. Blood samples were collected from different numbers of animals per breed, of both sexes. After DNA extraction PCR was carried out by using $25 \mu \mathrm{L}$ reaction mixture containing $3 \mathrm{mM}$ $\mathrm{MgCl}_{2}, 100 \mu M$ each of dATP, dCTP, dGTP, dTTP, $0.2 \mu M$ primer, $15 \mathrm{ng}$ of genomic DNA, and 5 unit of Taq polymerase, through programmable thermal cycler (Crea Con, TCY, USA).Out of 21 decamer primers 16 primers yielded easily scorable bright DNA bands while other five yielded smeared and nonspecific fragments. The genetic similarities of seven sheep breeds were high, ranging from $74.42 \%$ to $94.29 \%$. Thalli and Latti had greatest similarity (94.29\%). The lowest genetic similarity was between Lohi and Hissardale $(74.42 \%)$. The unweighted pair group method of arithmetic means (UPGMA) dendrogram obtained from the cluster analysis revealed two clusters. The study confirms that the molecular genetic techniques such as RAPD-PCR can economically and efficiently be used to establish genetic distances and similarities among and within breeds as well as to find out breed specific genetic markers. The seven sheep breeds in the study could be identified by using one breed specific RAPD marker or a combination of two or more markers. Primer GLB-08 can identify Lohi breed and primer GLA-14 can identify Hissardale. Primer GLA-19 can identify both Kajli and Sipli breeds simultaneously.
\end{abstract}

Keywords Sheep, Punjab, Thalli, Lohi, Kajli, RAPD-PCR

\section{Introduction}

Sheep and goat were perhaps the first ruminants to be domesticated around 10,000 B.C. Sheep were first domesticated probably in Iran and Baluchistan and what is now the Near East. Domesticated sheep existed in Harappa and Mohenjo-Daro. Most of the present breeds of sheep have traces of Mediterranean as well as Asian wild sheep [12]. The Pakistani sheep breeds most probably descended from urial (Ovis vignei), the wild sheep of Baluchistan, Afghanistan, and the central Asian area, as well as from the argali (Ovis ammon), and the Marco Polo sheep of China. At present there are 28 sheep breeds in Pakistan [21]. There are 25.5 million heads of sheep in Pakistan producing 40.7 metric tons of wool and contributing a reasonable amount of mutton (782.1 metric tons) together with goat population [3].

Livestock diversity is shrinking rapidly. Among the domesticated animal populations, it is estimated that 1 to 2 breeds are lost every week. So there is an urgent need to define strategies to prioritize breed conservation [10].The need for conservation comes from the potential rate of decrease of genetic variation. The loss of genetic variation within and between breeds is detrimental. Once animal genetic diversity has been lost, it can not be replaced. Indigenous and locally developed sheep breeds are an important asset for many reasons, particularly because, over time, they have developed unique combinations of adaptive traits to best respond to pressures of local environment [4].

Conservation of genetic resources requires the characterization of the available stock for preservation and management as well as evaluation of the phylogenetic origins of the genetic groups available [18]. In the recent years, several new and sophisticated methods have been developed to screen the polymorphism at the DNA level. A recent technique capable of detecting DNA based polymorphism is random amplified polymorphic DNA (RAPD) analysis. It is based on random amplification using polymerase chain reaction (PCR) with oligonucleotide primers. Single primer can be used to amplify genomic DNA and that polymorphism can be detected between the amplification products of different individuals. Polymorphism between individuals can arise through (1) nucleotide changes that prevent amplification by introducing 
a mismatch at one priming site (2) deletion of a priming site (3) insertion that render priming sites to distant to support amplification (4) insertions or deletions that change the size of the amplified product [26].

Efficient use of RAPD markers requires DNA isolation, optimum amplification conditions and appropriate data analysis. Thus, the present study was planned to determine molecular genetic variation among sheep breeds (Buchi, Hissardale, Kajli, Lohi, Sipli, Thalli and Salt Range) of Punjab province, Pakistan by using RAPD analysis with the following objectives:

- To optimize conditions for RAPD-PCR amplification for sheep genomic DNA.

- $\quad$ To construct a dendrogram among seven sheep breeds of the Punjab province in Pakistan on the basis of genetic variation.

\section{Materials and Methods}

The animals from sheep breeds (Buchi, Hissardale, Kajli, Lohi, Sipli, Thalli and Salt Range) of Punjab province were sampled according to their spatial distribution keeping in view the breed characteristics and where possible, pedigrees were consulted to ensure that animals were unrelated. Blood samples were collected from animals kept at different livestock farms, under the supervision of Livestock and Dairy Development Department (L\&DD) Punjab. Blood samples were taken from various numbers of animals per breed, aseptically from jugular vein in properly labeled $5 \mathrm{ml}$ potassium Ethylene Diamine Tetra acetic Acid (EDTA) vacutainers. Blood samples were immediately transferred to ice and later stored at $-20^{\circ} \mathrm{C}$ till further processing. High molecular weight genomic DNA were extracted from the frozen peripheral whole blood according to the FBI protocol reported by Signer et al. (1988) and Grimberg et al. (1989) with some slight modifications [9,22]. The concentration of total genomic DNA was calculated by measuring Optical Density (OD) at $260 \mathrm{~nm}\left(1 \mathrm{OD}_{260}=50 \mu \mathrm{g}\right.$ of double stranded $\mathrm{DNA} / \mathrm{ml}$ ) on UV visible spectrophotometer.

Table 1. PCR reaction components along with their concentrations

\begin{tabular}{|l|l|}
\hline Reagents & $1 \mathrm{Rx}(\mu \mathrm{L})$ \\
\hline $\mathrm{d}_{3} \mathrm{H}_{2} \mathrm{O}$ & $7.0 \mu \mathrm{l}$ \\
\hline 10X PCR buffer & $2.5 \mu \mathrm{l}$ \\
\hline Gelatin $(0.025 \%)$ & $2.5 \mu \mathrm{l}$ \\
\hline $\mathrm{MgCl}_{2}(3 \mathrm{~m} M)$ & $3.0 \mu \mathrm{l}$ \\
\hline $\mathrm{dNTPs}(2.5 \mathrm{~m} M)$ & $4.0 \mu \mathrm{l}$ \\
\hline Primer $(15 \mathrm{ng} / \mu \mathrm{L})$ & $2.0 \mu \mathrm{l}$ \\
\hline Taq Polymerase $(5 \mathrm{U} / \mu \mathrm{L})$ & $1.0 \mu \mathrm{l}$ \\
\hline Template DNA $(15 \mathrm{ng} / \mu \mathrm{L})$ & $3.0 \mu \mathrm{l}$ \\
\hline Total Volume & $25 \mu \mathrm{L}$ \\
\hline
\end{tabular}

The DNA bulks of each breed were prepared by pooling equal quantities of DNA from available number of individuals. PCR was carried out in $25 \mu \mathrm{L}$ reaction mixture containing $3 \mathrm{mM} \mathrm{MgCl}$, $100 \mu M$ each of dATP, dCTP, dGTP, dTTP, $0.2 \mu M$ primer, 15 ng of genomic DNA, and 5 unit of Taq polymerase, through programmable thermal cycler (Crea Con, TCY, USA). A total of 21 primers were used for the analysis. The thermal cycler was programmed for 5 minutes initial denaturation at $94^{\circ} \mathrm{C}$ for first cycle, followed by 1 minute denaturation at $94^{\circ} \mathrm{C}, 1$ minute primer annealing at $36^{\circ} \mathrm{C}$ and 2 minutes extension at $72^{\circ} \mathrm{C}$ for next 40 cycles and then final extension at $72^{\circ} \mathrm{C}$ for 10 minutes. PCR reaction components are given under in table 1.

The PCR products were electrophoresed at $50 \mathrm{~V}$ in $1.2 \%$ agarose gel for approximately 2 hours using $0.5 \mathrm{X}$ Tris Boric Acid EDTA (TBE) buffer containing ethidium bromide (10 $\mathrm{ng} / 100 \mathrm{~mL}$ agarose solution in TBE). The fingerprints were examined under ultra violet illuminator and photographed using the Uvitec Gel Documentation Still Video System.

Amplification profiles of seven sheep breeds were compared with each other and bands of DNA fragments were scored as present (1) or absent (0). The data of the primers were used to estimate genetic similarity (GS) on the basis of number of shared amplification products [16]. The coefficients were calculated by the following statistical equation;

$$
\begin{gathered}
\mathrm{GS}_{(\mathrm{ab})}=2 \mathrm{~N}_{\mathrm{ab}} /\left(\mathrm{N}_{\mathrm{a}}+\mathrm{N}_{\mathrm{b}}\right) \\
\mathrm{D}_{(\mathrm{ab})}=-\ln \left(\mathrm{GS}_{\mathrm{ab}}\right)
\end{gathered}
$$

Where,

GS is the genetic similarity coefficient and D is the genetic distance in which $\mathrm{N}_{\mathrm{a}}$ and $\mathrm{N}_{\mathrm{b}}$ are the numbers of fragments in breed $a$ and $b$, respectively, whereas Nab is the fragment shared by the two populations.

Similarity coefficients were utilized to generate a phylogenetic tree (dendrogram) by using unweighted pair group method of arithmetic means (UPGMA) [23].

\section{Results and Discussion}

Pooled DNA of seven sheep breeds were amplified with 21 different random primers. Five primers amplified no fragments or yielded smeared bands that could not be clearly identified. A total of 53 DNA fragments were generated by the remaining 16 primers with an average of about 3.3 bands per primer. The number of DNA fragments amplified with each primer was in a range reported in different studies using the random primers $[5,19]$. Bands that a primer yielded in this study ranged from one to six. Generally, the size and number of the fragments produced strictly depended upon the nucleotide sequence of the primer used and upon the source of the template DNA. To check the consistency of the amplified products, reactions were duplicated from time to time. Only easily resolved bright DNA bands were considered and scored.

All the breeds showed variation with each other on their amplification profile bases. Of the total 53 DNA bands amplified by 16 primers, 16 fragments showed polymorphism among seven sheep breeds, which is an approximately $30.19 \%$ polymorphism. The rest of the 37 
bands (69.81\%) were monomorphic in all seven sheep breeds. These results indicated that the level of DNA variation was low among the seven sheep breeds. These seven sheep breeds could be identified by using one breed specific RAPD marker or a combination of two or more markers. Primer GLB-08 can identify Lohi breed and primer GLA-14 can identify Hissardale. Primer GLA-19 can identify both Kajli and Sipli breeds simultaneously. Therefore RAPD markers can be used for identification of sheep breeds. Out of seven breeds studied, Kajli sheep produced the maximum number of DNA fragments (46) while minimum numbers of fragments (40) were produced by Hissardale.

Table 2. List of sixteen RAPD primers amplified and total number of fragments scored for each primer

\begin{tabular}{|c|c|c|c|}
\hline Primer & $\begin{array}{c}\text { Amplified } \\
\text { Fragments }\end{array}$ & Primer & $\begin{array}{c}\text { Amplified } \\
\text { Fragments }\end{array}$ \\
\hline GLA-08 & 1 & GLB-04 & 6 \\
\hline GLA-13 & 3 & GLB-05 & 1 \\
\hline GLA-14 & 3 & GLB-06 & 4 \\
\hline GLA-15 & 2 & GLB-07 & 4 \\
\hline GLA-18 & 3 & GLB-08 & 4 \\
\hline GLA-19 & 2 & GLB-10 & 5 \\
\hline GLA-20 & 3 & GLB-15 & 4 \\
\hline GLB-01 & 4 & GLB-17 & 4 \\
\hline
\end{tabular}

\section{Genetic Similarity among sheep breeds}

The genetic similarity matrix of RAPD data for the seven sheep breeds was constructed based on Nei and Li's (1979) coefficient of similarity and is shown in table. The genetic similarity of seven sheep breeds were high, ranging from 0.9429 to 0.7442 .

\section{Genetic Similarity among sheep breeds}

Nei's standard genetic distance (D) was calculated from
RAPD-PCR data to estimate the molecular genetic variation among seven sheep breeds. Genetic distance among these breeds was very low in the range of 0.0588 to 0.2954 . the maximum genetic distance was found between Lohi and Hissardale, while, minimum genetic distance was found between Thalli and Salt Range (Latti) (0.0588).

Template DNA concentration of $15 \mathrm{ng} / \mathrm{uL}$ was found to be optimum. The optimum concentration of $\mathrm{MgCl}_{2}$ was found to be $3 \mathrm{mM} . \mathrm{MgCl}_{2}$ concentration has a profound effect on DNA amplification. Five unit $/ 25 \mathrm{uL}$ reaction mixtures were found optimum. The optimum annealing temperature found in this study was $36^{\circ} \mathrm{C}$. Forty cycles per reaction was found optimum. Random amplified polymorphic DNA (RAPD) produced consistent results with optimized conditions and have potential to be employed for molecular genetic variations and taxonomy classification. The observed polymorphism in the present study was $30.19 \%$, while $69.81 \%$ fragments were monomorphic. The probability of finding these short decamer primer cognate sequences in the target DNA varies and may be numerous, such that a single primer generates multiple amplification fragments.

Forty two animals were analyzed out of the sixty nine selected for blood collection. Genomic DNA of six animals from each breed was extracted and pooled to make bulks by mixing equal quantity of DNA from each individual. Nei's standard genetic distance among seven breeds was very low in the range of 0.2954 to 0.0588 . In the present study the maximum genetic distance was found between Lohi and Hissardale (0.2954), while, minimum genetic distance was found between Thalli and Salt Range (Latti) (0.0588). On the other hand the genetic similarities of seven sheep breeds were high, ranging from $94.29 \%$ to $74.42 \%$. Thalli and Latti had greatest similarity $(94.29 \%)$. The unweighted pair group method of arithmetic means (UPGMA) dendrogram obtained from the cluster analysis revealed two clusters.

Table 3. Similarity Matrix of seven sheep breeds obtained from RAPD markers

\begin{tabular}{|c|c|c|c|c|c|c|c|}
\hline Breeds & Thalli & Lohi & Salt Range & Kajli & Sipli & Buchi & Hissardale \\
\hline Thalli & 1 & & & & & & \\
\hline Lohi & 0.9102 & 1 & & & & & \\
\hline Salt Range & 0.9429 & 0.8471 & 1 & & & & \\
\hline Kajli & 0.8414 & 0.8033 & 0.8428 & 1 & & & \\
\hline Sipli & 0.9020 & 0.8639 & 0.9034 & 0.9380 & 1 & & \\
\hline Buchi & 0.9388 & 0.8490 & 0.8830 & 0.8525 & 0.9224 & 1 & 1 \\
\hline Hissardale & 0.7823 & 0.7442 & 0.8346 & 0.8653 & 0.8442 & 0.7666 & \\
\hline
\end{tabular}

Table 4. Nei's standard genetic distance (D) among seven sheep breeds of the Punjab province.

\begin{tabular}{|c|c|c|c|c|c|c|c|}
\hline Breed & Thalli & Lohi & Salt Range & Kajli & Sipli & Buchi & Hissardale \\
\hline Thalli & 0 & 0.0941 & 0.0588 & 0.1727 & 0.1031 & 0.0632 & 0.2455 \\
\hline Lohi & & 0 & 0.1659 & 0.2190 & 0.1463 & 0.1637 & 0.2954 \\
\hline Salt Range & & & 0 & 0.1710 & 0.1016 & 0.1244 & 0.1808 \\
\hline Kajli & & & & 0 & 0.0640 & 0.1596 & 0.1447 \\
\hline Sipli & & & & & 0 & 0.0808 & 0.1694 \\
\hline Buchi & & & & & & 0 & 0.2658 \\
\hline Hissardale & & & & & & & 0 \\
\hline
\end{tabular}




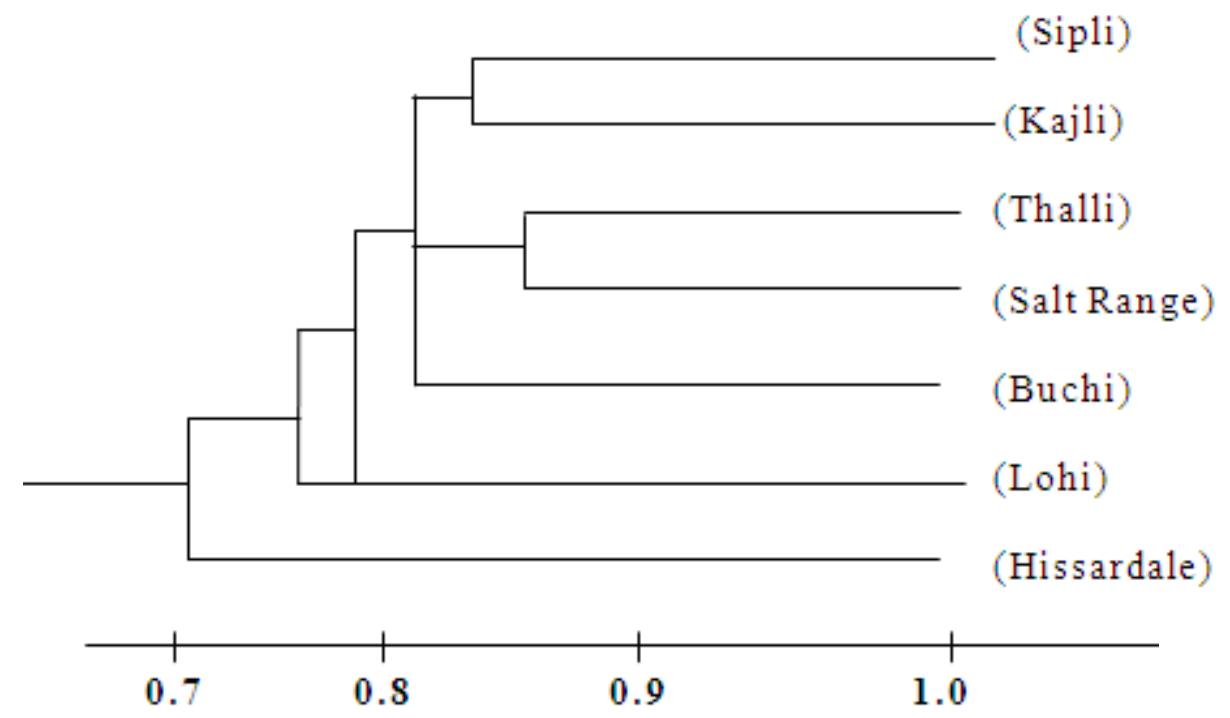

Figure 1. Phylogenetic relationships among some Punjab Sheep breeds generated by RAPD data using UPGMA method

\section{Conclusions}

Genetic distance among these breeds was low in the range of 0.0588 to 0.2954 . The low levels of genetic variation among these breeds indicate the high degree of genetic relationships. This increase in the relatedness among these indigenous breeds is the result of haphazard and indiscriminate crossbreeding in the home tracts of the respective breeds, and lack of the implementation of the provincial and national breeding policies in the country. For molecular genetic studies, sophisticated inputs such as; authenticity of pedigree, appropriate selection of molecular technique, availability of a prior knowledge about the genome of respective species, stipulation of good working conditions, latest equipments and laboratories are of supreme importance. A large number of primers from different companies, more number of animals from each breed with authentic pedigree recording and sampling from breed home tracts is also suggested along with more advanced molecular genetics techniques using microsatellites such as SSR, in order to refine the relationship.

\section{REFERENCES}

[1] Ali, B. A. 2003. Genetics similarity among four breeds of sheep in Egypt detected by random amplified polymorphic DNA markers. Afr. J. Bioteh. 2 (7): 194-197.

[2] Anbarasan, K., A. K. Sharma, R. K. Singh, S. M. Deb, D. Sharma and N. K. Mazumdar. 2002. Genetic relatedness among descript and non-descript goats using randomly amplified polymorphism DNA (RAPD). Ind. J. Anim. Sci. 72(1): 96-98.

[3] Anonymous. 2006. Economic survey 2006. Government of Pakistan. Advisor's Wing, Ministry of Finance, Islamabad.
[4] Buduram, P. 2005. Genetic Characterization of Southern African Sheep Breeds using DNA markers. M.Sc. thesis, Dept. of Animal, Wildlife and Grassland Sciences, University of the Free State.

[5] Chen, S., M. Li, Y. Li, S. Zhao, C. Yu, M. Yu, B. Fan and K. Li. 2001. RAPD variation and genetic distances among Tibetan, Inner Mangolia and Liaoning Cashmere goats. Asian-Aust. J. Anim. Sci. 14(11): 1520-1522.

[6] Cushwa, W. T., K. G. Dodds, A. M. Crawford and J. F. Medrano. 1996. Identification and genetic mapping of random amplified polymorphic DNA (RAPD) markers to the sheep genome. Mamm. Genome. 7(8): 580-585.

[7] FAO (1997). The Global Strategy for the Management of Farm Animal Genetic Resources; a call for Action. FAO Publishing, Rome.

[8] Geng, S. M., W. Shen, G. Q. Qin, X. Wang, S. R. Hu, Q. L. Wang and J. Q. Zang. 2002. DNA fingerprint polymorphism of 3 goat population from China Chaidamu Basin. Asian-Aust. J. Anim. Sci. 15(8): 1076-1079.

[9] Grimberg, J., S. Nawoschik, L. Belluscio, R. Mckee, A. Turck and A. Eisenberg. 1989. A simple and efficient non-organic procedure for the isolation of genomic DNA from blood. Nucl. Acids Res. 17: 8390.

[10] Hanotte, O. and H. Jianlin. 2005. Genetic Characterization of Livestock populations and its uses in Conservation Decision Making. The Role of Bitechnology. Villa Gualino, Turnin, Italy. (5-7 March).

[11] Hash, C. T. and P. J. Bramel-Cox. 2000. Application of molecular markers in plant breeding. IITA-Ibadan, Nigeria. (16-17 Aug). pp. 3-12.

[12] Hasnain, H. U. 1985. Sheep and Goats in Pakistan. F.A.O. Animal Production and Health paper 56.

[13] Li, B., M. Du, X. Guo and Z. Zhou. 2002. Genetic analysis of Shanxi native goats using RAPD markers. Proc. $7^{\text {th }}$ World Cong. Genet. Appl. Livest. Prod. (19-23 August) Montpellier, France. Communication No. 26-50. 
[14] Li, Y. J., S. L. Chen, N. Ma, S. H. Zhao, Y. X. Cao and Cwainandobuj. 1998. Random amplified polymorphic DNA study of Tibetan Cashmere goat. Proc. $6^{\text {th }}$ World Cong. Genet. Appl. Livest. Prod. (11-16 January) Armidale, NSW, Australia. 24: 103-106.

[15] Mateus, J.C., M.C.T.Penedo, V.C.Alves, M.Ramos and T.Rangel-Figueiredo.2004. Genetic diversity and differentiation in Portuguese cattle breeds using microsatellite. International Society for Animal Genetics, Animal Genetics (6): 106-113.

[16] Nei, N. and W. Li. 1979. Mathematical model for studying genetic variation in terms of restriction endonucleases. Proc. Natl. Acad. Sci. 76: 5269-5273.

[17] Oliveira, R. R., A. A do Egito, M. N. Riberio, S. R. Paiva, M. S. M. Albuquerque, S. R. Castro, A. S. Mariante and M. Adrio. 2005. Genetic characterization of Moxoto goat breed using RAPD markers. Pesq. agropec. bras., Brasilia, V. 40, n3. Pp. 233-239.

[18] Paiva, S. R., D. A. Faria, V. C. Silverio, C. McManus, A. A. Egito, J. A. Dergan, S. E. F. Guimaraes, S. R. Castro, M. S. M. Albuquerque and A. S. Mariante. 2005. Genetic variability among Brazilian sheep using microsatellites. The Role of Biotechnology. Villa Gualino, Turin, Italy. (5-7 March).

[19] Rahman, M.., D. Hussain and Y. Zafar. 1999. DNA Fingerprinting: Creating new opportunities-A Review. Proc.First SESCOB Conference. 2(1-4): 129-139.

[20] Serrano, G. M., A. A. Egito, C. McManus and A. Da. S. Mariante. 2004. Genetic diversity and population structure of
Brazilian native bovine breeds. Pesq.agropec. bras., Brasilia 39(6): 543-549.

[21] Shah, S. I. 1994. Animal Husbandry. National Book Foundation, Islamabad. Pp 61-73.

[22] Signer, E., C. C. Kuenzle, P. E. Thomann and U. Hubscher. 1988. DNA fingerprinting: Improved DNA extraction from small blood samples. Nucl. Acids Res. 16: 7738.

[23] Sneath, P. H. A. and R. R. Sokal. 1973. Numerical Taxonomy. Freeman, San Francisco

[24] Stephen, J., Wollny, C. B. A. and P. S. Gwakisa. 2001. Genetic relationship among five ecotypes of sheep in Tanzania. In: Proceedings of "Community Based Management of Animal Genetic Resources-A tool for rural development and food security". May $7^{\text {th }}$ to $11^{\text {th }}$, Mbabane, Swaziland.

[25] Sun, W., H. Chang, Z.J. Ren, Z.P. Yang, R.Q. Geng, S.X. Lu, L. Du and K. Tsunoda. 2004. Genetic differentiation between sheep and goats based on microsatellite DNA. Asian-Aust. J. Anim. Sci. 17(5): 583-587.

[26] Williams J. G., A. R. Kubelik, K. J. Livak, J. A. Rafalski and S. V. Tingey. 1990. DNA polymorphisms amplified by arbitrary primers are useful as genetic markers. Nucl. Acids Res. 25:18(22): 6531-6535.

[27] Zhang, W., Y. Chao, J. Li and G. Wu. 2002. Assessment of genetic variability based on DNA polymorphism in Nei Mongol Cashmere goats. Proc. 7th World Cong. Genet. Appl. Livest. Prod. (19-23 August) Montpellier, France. Communication No. 26-30. 